\title{
Dampak Poligami Bawah Tangan Terhadap Hak Anak Di Daerah Transmigrasi
}

\author{
${ }^{1}$ Rahmawati, ${ }^{2}$ Wiwin Putriawati ${ }^{3}$, Leni Nurul Kariyani ${ }^{4}$ \\ ${ }^{1,2}$ STKIP Paracendekia NW Sumbawa \\ ${ }^{3}$ Institut Ilmu Sosial dan Ilmu Budaya Samawa Rea \\ Email: rahmawatistkip@gmail.com, putriawatiw29@gmail.com, Leniiisbud@gmail.com
}

\begin{abstract}
Abstrak: Poligami bawah tangan merupakan hal yang sangat kontroversial di Indonesia. Poligami bawah tangan sah menurut hukum Islam namun tidak tercatat di KUA sehingga tidak memiliki legal hukum. Hasil observasi awal peneliti terhadap kasus poligami ini yang terjadi di daerah transmigrasi yaitu di desa Prode II Kecamatan Plampang Kabupaten Sumbawa, Nusa Tenggara Barat adalah banyaknya anak yang tercatat sebagai anak Ibu. Tidak adanya buku nikah mengakibatkan akta kelahiran anak tidak bisa dibuat, padahal akta kelahiran menjadi salah satu syarat untuk mendapatkan pendidikan. Adapun tujuan penelitian ini adalah untuk mengetahui dampak poligami bawah tangan terhadap hak anak di daerah transmigrasi agar dapat memberikan solusi dalam menyelesaikan masalah pemenuhan hak anak sebagai warga Negara Indonesia. Metode penelitian yang digunakan yaitu penelitian kualitatif dengan menggunakan pendekatan studi kasus. Objek dalam penelitian ini adalah dampak poligami terhadap hak anak di desa Prode II kecamatan Plampang Kabupaten Sumbawa Provinsi NTB. Subjek penelitian ini adalah pelaku poligami bawah tangan, istri dan anaknya. Metode pengumpulan data dengan observasi langsung, wawancara mendalam dan dokumentasi. Peneliti menekankan pada uji kredibilitas data atau kepercayaan terhadap hasil penelitian melalui beberapa tahap antara lain: memperpanjang pengamatan, meningkatkan ketekunan dalam penelitian, melaksanakan triangulasi sumber data maupun teknik pengumpulan data, melakukan diskusi dengan sejawat/orang yang berkompeten menyangkut persoalan yang sedang diteliti, serta mengadakan member check untuk memastikan kesesuaian data yang telah diberikan oleh pemberi data. Hasil penelitian dari data studi kasus di Desa Prode II terdapat 62 anak yang belum memiliki akta kelahiran karena belum memiliki persyaratan yang lengkap, seperti buku nikah, KTP dan KK. Pernikahan di bawah tangan memiliki akibat hukum yang sangat merugikan anak karena anak-anak tidak mendapatkan akta kelahiran dari Bapak yang berwenang. Oleh karena itu, untuk mendapatkan akta kelahiran diperlukan akta nikah dari orang tua. Selain itu juga, anak tidak dapat mewarisi harta Bapak karena tidak ada bukti autentik yang menyatakan mereka sebagai ahli warisnya dan juga tidak memperoleh hak-hak lainnya dalam pelaksanaan administrasi negara yang mesti harus dipenuhi sebagai identitas warga Negara Indonesia.
\end{abstract}

Kata Kunci : Poligami, Hak Anak, Transmigrasi

\section{PENDAHULUAN}

Poligami adalah mengawini beberapa wanita atau istri di waktu yang bersamaan. Berpoligami berarti menjalankan (melakukan) poligami. Istilah poligami sama dengan poligyni, yaitu mengawini beberapa wanita dalam waktu yang sama (Arifin, 2010: 291).

Islam juga memperbolehkan perkawinan poligami (suami yang mempunyai istri lebih dari seorang). Walaupun poligami pada masa sekarang ini merupakan sebuah fenomena sosial dalam masyarakat, dimana fenomena poligami pada saat ini menemui puncak kontroversinya, begitu banyak tanggapantanggapan dari khalayak mengenai poligami, baik yang pro ataupun kontra. Masalah poligami bukanlah masalah baru, begitu banyak pertentangan di dalamnya yang sebagian besar dinilai karena perbedaan pandangan masyarakat dalam memberikan sudut pandang pada 
Jurnal Ilmu Sosial dan Pendidikan

http://ejournal.mandalanursa.org/index.php/JISIP/index

Terakreditasi Peringkat 5 (No. SK: 85/M/KPT/2020)

berbagai hal yang terkait masalah poligami baik ketentuan, batasan, syarat, masalah hak, kewajiban, kebebasan dan hal-hal lainnya.

Menurut Islam, Poligami dipandang sebagai salah satu cara untuk menjaga kebaikan masyarakat, menghindarkannya dari bahaya besar yang ditimbulkan oleh temperamen sebagian anggotanya dan oleh berbagai macam keinginan di kalangan kaum suami istri. Umpamanya, ada sebagian orang yang memiliki nafsu seks yang tinggi dan tidak cukup hanya seorang istri. Untuk menghindarkan orang tersebut dari berbuat zina (pergi ke pelacuran) maka di bolehkan berpoligami (Junaedi, 2003: 239)

Pada asasnya dalam suatu pernikahan seorang pria hanya boleh mempunyai seorang istri dan seorang wanita hanya boleh mempunyai seorang suami. Namun Pengadilan Agama dapat memberikan izin kepada seorang suami untuk beristri lebih dari seorang apabila dikehendaki oleh pihak-pihak yang bersangkutan (Pasal 3 ayat 1 UU No. 1 Tahun 1974 Perkawinan).

Seorang laki-laki diperbolehkan berpoligami dengan syarat:

1. Adanya persetujuan dari istri atau istri-istri.

2. Adanya kepastian bahwa suami mampu menjamin keperluan-keperluan hidup istri-istri dan anakanak mereka.

3. Adanya jaminan bahwa suami akan berlaku adil terhadap istri-istri dan anakk-anak. (Undangundang No 1 Tahun 1974 pasal 5 ayat 1).

Kemudian Undang-undang Nomor 1 Tahun 1974 pasal 2 ayat (2) menjelaskan bahwa tiaptiap perkawinan di catat menurut peraturan perundang- undangan yang berlaku kemudian dalam Kompilasi Hukum Islam (KHI) pasal 5 ayat (1) Agar terjamin ketertiban perkawinan bagi masyarakat Islam setiap perkawinan harus dicatat. Sedangkan yang terjadi di masyarakat Indonesia pada umumnya banyak perkawinan yang tidak tercatat sehingga anak yang dilahirkan masuk ke kartu keluarga ibu yang tercatat sebagai anak ibu bukan anak bapak. Sehingga anak kesulitan untuk mendapatkan
Vol. 5. No. 1 Januari 2021

p-ISSN: 2598-9944 e-ISSN: 2656-6753

akte kelahiran yang menyebabkan hak yang bersangkutan sebagai warga Negara tidak terpenuhi secara maksimal. Kerena untuk mendapatkan pendidikan, bantuan pendidikan status sosial di masyarakat dan lain-lain harus tercatat secara sah sebagai warga Negara yang memiliki identitas legal. Kasus tersebut terjadi di daerah transmigrasi desa Prode kecamatan Plampang Kabupaten Sumbawa.

Adapun jumlah keseluruhan penduduk Desa Prode SP II tahun 2019 yaitu 354 KK, 560 penduduk laki-laki, 576 penduduk perempuan dengan jumlah keseluruhan penduduk adalah 1.175 penduduk.

Berdasarkan fenomena di atas, peneliti tertarik untuk mengangkat permasalahan ini menjadi sebuah penelitian agar menjadi perhatian bersama sehingga mendapatkan solusi sesuai dengan hukum yang ada di Indonesia dan anak mendapatkan hak yang sama sebagai warga Negara Indonesia dengan judul "DAMPAK POLIGAMI BAWAH TANGAN TERHADAP HAK ANAK DI DAERAH TRANSMIGRASI".

\section{Rumusan Masalah}

Adapun rumusan masalah dalam penelitian ini adalah "Bagaimana dampak poligami bawah tangan terhadap hak anak di daerah transmigrasi?".

\section{METODE PENELITIAN}

Jenis penelitian yang digunakan dalam penelitian ini adalah penelitian kualitatif. Dengan menggunakan pendekatan studi kasus. Penelitian kualitatif merupakan penelitian yang digunakan untuk meneliti pada kondisi objek yang alamiah yakni sesuatu yang apa adanya tidak dimanipulasi keadaan dan kondisinya. Lebih lanjut, Sugiyono menjelaskan bahwa penelitian kualitatif menempatkan peneliti sebagai instrumen kunci, teknik pengumpulan data dilakukan secara triangulasi (gabungan), analisis data bersifat induktif dan hasil penelitian lebih menekankan makna secara naratif. 
Jurnal Ilmu Sosial dan Pendidikan

http://ejournal.mandalanursa.org/index.php/JISIP/index

Terakreditasi Peringkat 5 (No. SK: 85/M/KPT/2020)

Di sisi lain, sudut pandang penelitian kualitatif tidak menggunakan istilah populasi melainkan atau situasi sosial yang terdiri dari tiga elemen yaitu; tempat (place), pelaku (actors) dan aktivitas (activity) yang berinteraksi secara sinergis. Bahkan pendapat yang senada juga diungkap oleh Emzir, mengartikan bahwa pendekatan kualitatif merupakan suatu bentuk penelitian yang berfokus pada makna sosiologis melalui observasi lapangan tertutup dari fenomena sosiokultural yang dapat diidentifikasi melalui wawancara dari berbagai informan-informan tentang fenomena yang sedang diteliti (Emzir, 2012:149). Penggunaan penelitian kualitatif sangat relevan dengan arah penelitian penulis, karena penelitian ini dimaksudkan untuk mendeskripsikan kondisi alamiah terkait dengan kasus dampak poligami bawah tangan terhadap hak anak di daerah transmigrasi.

Objek dalam penelitian ini adalah di desa Prode II kecamatan Plampang Kabupaten Sumbawa Provinsi Nusa tenggara Barat. Subjek penelitian ini adalah pelaku poligami bawah tangan, istri dan anaknya. Untuk mendapatkan solusi terbaik yang disesuaikan dengan kondisi sosial. Situasi sosial yang dimaksud dapat dinyatakan sebagai obyek/subyek penelitian yang ingin dipahami secara mendalam (Sugiyono, 2013: 29).

\section{HASIL DAN PEMBAHASAN}

Pernikahan adalah perbuatan hukum jadi segala sesuatu yang ditimbulkan akibat pernikahan adalah sah secara hukum. Mengingat pernikahan siri cacat secara hukum maka, tidak ada perlindungan hukum bagi suami istri ataupun anak. Masalah-masalah yang timbul mayoritas adalah masalah hukum. Harus diakui bahwa pernikahan siri rawan terhadap konflik. Baik konflik internal rumah tangga maupun konflik eksternal yang berhubungan dengan hukum dan masyarakat. Dampak perkawinan dbawah tangan bagi anak adalah :

Jurnal Ilmu Sosial dan Pendidikan
Vol. 5. No. 1 Januari 2021

p-ISSN: 2598-9944 e-ISSN: 2656-6753

\section{Anak hanya mempunyai hubungan perdata dengan ibu dan keluarga ibu.}

Anak-anak yang dilahirkan diluar perkawinan atau perkawinan yang tidak tercatat dianggap anak tidak sah, juga hanya memiliki hubungan perdata dengan ibu (pasal 42 dan 43 undang-undang no 1 tahun 1974) sedangkan hubungan perdata dengan ayahnya tidak ada.

2. Anak dan ibunya tidak berhak atas nafkah dan warisan.

Akibat lebih jauh perkawinan tidak tercatat adalah, baik istri ataupun anak anaknya yang lahir dari perkawinan tersebut tidak berhak menuntut nafkah ataupun warisan.

\section{Secara sosial}

Anak akan sulit bersosialisasi dan malu karena dianggap anak tidak sah secara hukum.

\section{Secara hukum}

Anak-anak yang dilahirkan di dalam pernikahan di bawah tangan menurut hukum negara memiliki dampak negatif bagi status anak yang dilahirkan di mata hukum karena anak yang dilahirkan dianggap anak yang tidak sah. Konsekuensinya anak hanya memiliki hubungan perdata dengan ibu dan keluarga ibu. Dalam akta kelahirannya pun status anak dianggap sebagai anak di luar nikah sehingga hanya dicantumkan nama ibu yang melahirkannya. Keterangan tentang status anak yang orang tuanya menikah di bawah tangan dan tidak tercantumnya nama Bapak akan berdampak sangat mendalam secara sosial dan psikologis bagi anak dan ibunya. Ketidak jelasan status anak di muka hukum membuat hubungan antara anak dan Bapak tidak kuat, sehingga bisa saja suatu waktu bapaknya menganggap bahwa anak tersebut bukan anak kandungnya. Akibatnya, tentu saja merugikan anak tersebut sehingga tidak berhak atas biaya pendidikan, nafkah dan warisan Bapaknya.

Berdasarkan uraian di atas maka pernikahan di bawah tangan hanya menguntungkan suami/laki-laki dan akan merugikan kaum perempuan dan anak.

Pencatatan pernikahan, secara syariat bukanlah syarat yang menentukan sahnya 
Jurnal Ilmu Sosial dan Pendidikan

http://ejournal.mandalanursa.org/index.php/JISIP/index

Terakreditasi Peringkat 5 (No. SK: 85/M/KPT/2020)

pernikahan. Namun adanya bukti autentik yang tertulis dapat menjadi salah satu alat memperkuat komitmen yang dibangun oleh pasangan tersebut. Walaupun memperkuat komitmen tidak terbatas pada akta nikahnya, karena akta nikah sendiri dapat dibatalkan melalui gugatan perceraian.

Jadi, berdasarkan data dari studi kasus di Desa Prode II terdapat 62 anak yang belum memiliki akta kelahiran karena belum memiliki persyaratan yang lengkap, seperti buku nikah, KTP dan KK.

\section{KESIMPULAN}

Pernikahan di bawah tangan memiliki akibat hukum yang sangat merugikan anak karena anak-anak tidak mendapatkan akta kelahiran dari ayah yang berwenang. Oleh karena itu, untuk mendapatkan akta kelahiran diperlukan akta nikah dari orang tua. Selain itu juga, anak tidak dapat mewarisi harta Bapak karena tidak ada bukti autentik yang menyatakan mereka sebagai ahli warisnya dan juga tidak memperoleh hak-hak lainnya dalam pelaksanaan administrasi negara yang mesti harus dipenuhi sebagai identitas warga Negara Indonesia.

Selanjutnya peneliti akan melakukan keberlanjutan penelitian ini guna membantu anak hasil pernikahan di bawah tangan untuk mendapatkan haknya seperti anak yang menikah yang diakui secara hukum dan agama salah satunya akta kelahiran.

\section{DAFTAR PUSTAKA}

Abdurahman, M. (2009). Praktik Poligami Bawah Tangan di Kecamatan Kota Utara Kota Gorantalo dan Implikasi dalam Perspektif Hukum Islam. Tesis. Makassar: UIN Alauddin Makassar.

Darmadi, H. (2013). Diminasi-diminasi Metode Penelitian Pendidikan dan Sosial. Cet. I; Bandung: Alfabeta.

Datin, R. (2007). Poligami dan Persepsi Khalayak (studi Deskriptif Teneang Pemberitaan Poligami di Tabloid Nava
Vol. 5. No. 1 Januari 2021

p-ISSN: 2598-9944 e-ISSN: 2656-6753

dan Persepsi Ibu-ibu Rumah Tangga di Kelurahan Asam Kumbang Kecamatan Medan Selayang). Skripsi. Medan: Universitas Sumatera Utara Medan.

Noviana, L. (2012). Persoalan Praktik Poligami dalam Masyarakat Islam, tesis (Malang: UNI Maulana Malik Ibrahim,).

Emzir. (2012). Metodologi Penelitian Pendidikan: Kuantitatif dan Kualitatif. Cet. VI; Jakarta: Rajagrafindo Persada.

Mursalin, S. (2007). Menolak Poligami, Studi tentang Undang-Undang Perkawinan dan Hukum Islam. Yogyakarta, Pustaka Pelajar.

Soemiyati. (1986). Hukum Perkawinan Islam dan Undang-Undang Perkawinan. Yogyakarta: Liberty.

Siti, M. (2004) Islam Menggugat Poligami, Jakarta: PT. Gramedia Pustaka Utama.

Yinyang Pusat Studi Gender STAIN Purwokerto ISSN: 1907-2791. Vol.5 No.1 Jan-Jun 2010 pp.143-167.

https://www.gurupendidikan.co.id/transmigrasipengertian-tujuan-dan-macam-macambeserta-contohnya-secara-lengkap diambil 12 agustus 2019.

Jurnal pendidikan kewarganegaraan: volume 6, nomor 11, mei 2016 